\title{
Reproductive characteristics, egg and larval development of short ninespine stickleback, Pungitius kaibarae
}

\author{
In Joon Hwang ${ }^{1, \#, *}$, Si Woo Lee, ${ }^{2, \#}$, Young Sim Han ${ }^{1}$, Kyeong Hwan Kim" \\ ${ }^{1}$ Inland Fisheries Research Institute, National Institute of Fisheries Science, Geumsan 32762, Korea \\ ${ }^{2}$ Southeast Sea Fisheries Research Institute, National Institute of Fisheries Science, Tongyeong 53085, Korea
}

\begin{abstract}
In this study, the reproductive behavior and embryonic and larval development of the short ninespine stickleback Pungitius kaibarae was described and illustrated based on observations during spawning, hatching, and larval rearing trials. Adult $P$. kaibarae were collected downstream in Jinhae during the reproductive season (April-May). Males had nuptial coloration on their entire black bodies, with blue dorsal spines and yellow eyes, whereas females had a brown spotted pattern on their bodies. Males built nests on the stems of water weeds and attracted females. Fertilization occurred in the nest immediately after spawning, and males guarded the eggs until hatching. The fertilized eggs of $P$. kaibarae were spherical, demersal, adhesive, and transparent, and each egg measured $1.43 \pm 0.07 \mathrm{~mm}$ in diameter. The morula, blastula, and gastrula stages, as well as hatching began at 5 , $18.5,21.5$, and 96 post fertilization (HPF) , respectively, at $20.0 \pm 0.5^{\circ} \mathrm{C}$. The newly hatched larvae had a total length (TL) of $5.67 \pm$ $0.50 \mathrm{~mm}$, with a yolk volume of $0.583 \pm 0.059 \mathrm{~mm}^{3}$. Their mouths and anuses had not yet opened. At 2 days posthatching (days post hatching, DPH), the yolk was completely absorbed and the larvae began to feed exogenously. Pigmentation was observed in freshly hatched larvae $4 \mathrm{~h}$ after hatching, with the presence of eight areas with a dotted pattern on the dorsal surface of the larvae and dispersed spots on the head and yolk sac. At $30 \mathrm{DPH}$, the TL of the juveniles was $21.34 \pm 1.70 \mathrm{~mm}$. The nest area and number of eggs were $259.56 \pm 101.39 \mathrm{~mm}^{2}(75.18-506.04)$ and $155.33 \pm 114.12$ (0-437), respectively.
\end{abstract}

Keywords: Egg development, Larvae, Reproductive behavior, Short ninespine stickleback

\section{Introduction}

The short ninespine stickleback, Pungitius kaibarae, is a freshwater species belonging to the family Gasterosteidae within the order Gasterosteiformes. There are five genera and 18 species reported in total, whilst two genera and five species, including P. kaibarae, Pungitius sinensis (P. sinensis), Pungitius tymensis ( $P$. tymensis), Pungitius pungitius (P. pungitius), and Gasterosteus

Received: Jul 30, 2021 Revised: Sep 15, 2021 Accepted: Oct 6, 2021

\#These authors contributed equally to this work.

${ }^{\star}$ Corresponding author: In Joon Hwang

Inland Fisheries Research Institute, National Institute of Fisheries Science, Geumsan 32762, Korea

Tel: +82-41-750-1061, Fax: +82-41-750-1015, E-mail: astraroth@korea.kr

This is an Open Access article distributed under the terms of the Creative Commons Attribution Non-Commercial License (http://creativecommons.org/licenses/by$\mathrm{nc} / 4.0 /$ ) which permits unrestricted non-commercial use, distribution, and reproduction in any medium, provided the original work is properly cited.

Copyright $(9) 2021$ The Korean Society of Fisheries and Aquatic Science 
aculeatus (G. aculeatus), have been reported in Korea (Kim et al., 2005; http://www.fishbase.org). P. kaibarae is a small gasterosteid fish that is distributed in Russia and Japan and is native to the east coast of the Korean Peninsula. They inhabit only some rivers that drain into the East Sea (Bae et al., 2017; Kim et al., 1989; Kim, 1997 ). This species was designated as an endangered species in Korea until 2012 and as a near-threatened (NT) species since 2016 (MEK, 2016).

Sticklebacks have been used as a model species in various studies owing to their short life span, specific reproductive behavior, including building a nest, and territorial behavior (Hahlbeck et al., 2004; Sokołowska \& Kulczykowska, 2006). To date, studies on the courtship and territorial behavior, population structure, and genomics of $P$. kaibarae have been reported (Bae \& Suk, 2015; Jang et al., 2006; Hwang et al., 2012; Park \& Lee, 1999; Park et al., 2001). However, there exists no detailed ontogenetic profile of the early life history, including egg/larval development, of the short ninespine stickleback. Research on the early life history of fish can be used as important data in breeding ecology and applied to related subjects such as conservation or restoration of endangered or endemic species (Blaxter, 1974).

In the present study, we explored spawning behavior and egg and larval development in order to provide fundamental information on the reproductive biology of $P$. kaibarae, a Korean endemic species.

\section{Materials and Methods}

\section{Fish sampling and rearing condition}

Short ninespine sticklebacks ( $P$. kaibarae) were collected downstream from Jinhae, South Korea, from April to May, 2019, using a scoop net. Fish (100 males and 200 females) were moved into a continuous flow-through indoor tank $\left(2 \mathrm{~m}^{3}\right)$ and maintained under a photoperiod of $14 \mathrm{~L}: 10 \mathrm{D}$ at $20.0 \pm 0.5^{\circ} \mathrm{C}$. Fine sand was placed on the bottom of the fish tank and water weeds from their natural habitat were planted to enable the fish to build nests. Fish were fed a commercial feed and frozen mosquito larvae.

\section{Observation of spawning and fertilization}

Published literature include drawings of the spawning behavior of short ninespine sticklebacks (P. kaibarae) (Park et al., 2001). However, there are no digital photography data available. In the present study, videos and pictures were created using a digital camera when males had nuptial body coloring, as described by
Park et al. (2001), until spawning.

The spawned and hatched larvae in each nest were counted. The bulk area of the nest, the area covered by a portion of the nest through which no basal substratum was visible, was calculated. The number of spawned and hatched larvae and nest area were compared with those of other stickleback species.

\section{Embryo and larval development}

After spawning, 10-15 fertilized eggs were carefully separated from the nests. The embryonic development of $P$. kaibarae was observed using a dissection microscope. After hatching, the total length (TL) of newly hatched larvae was measured at intervals of $5 \mathrm{~d}$ using a dissection microscope. During the rearing process, larvae were fed 5-10 Artemia from 3 days post hatching $(\mathrm{DPH})$. Water temperature and photoperiod during the rearing period were $20.0 \pm 0.5^{\circ} \mathrm{C}$ and $14 \mathrm{~L}: 10 \mathrm{D}$, respectively.

\section{Measurement of nest area and number of eggs}

Several nests were harvested after spawning, and their bulk area $\left(\mathrm{mm}^{2}\right)$, the area covered by a portion of the nest through which no basal substratum was visible was calculated by measuring width ( $\mathrm{mm})$ and height $(\mathrm{mm})$ according to the method of Barber et al. (2001). Then, the spawned and hatched larvae in each nest were counted.

\section{Results}

\section{Spawning and fertilization}

Males had nuptial coloration on their entire black bodies, with blue dorsal spines and yellow eyes, whereas females had a brown spotted pattern on their bodies (Fig. 1A and 1B). Males built nests on the stems of water weeds and attracted females. Fertilization occurred in the nest immediately after spawning (Fig. 1C), and males guarded the eggs until they hatched (Fig. $1 \mathrm{D}$ and $1 \mathrm{E})$.

\section{Embryo and larval development}

The fertilized eggs of $P$. kaibarae were spherical, demersal, adhesive, and transparent, and a single egg measured $1.43 \pm 0.07$ $\mathrm{mm}$ in diameter. Ten minutes post fertilization, accumulation of cytoplasm took place, and the blastodisc was formed from the animal pole (Fig. 2A). The eggs reached 2, 4, 8, and 16 cell-stages (Fig. 2B-2E) at $0.5,1,1.5$, and 2 post fertilization (HPF), respectively.

At $4 \mathrm{HPF}$, eggs reached the morula stage and the cells of the 

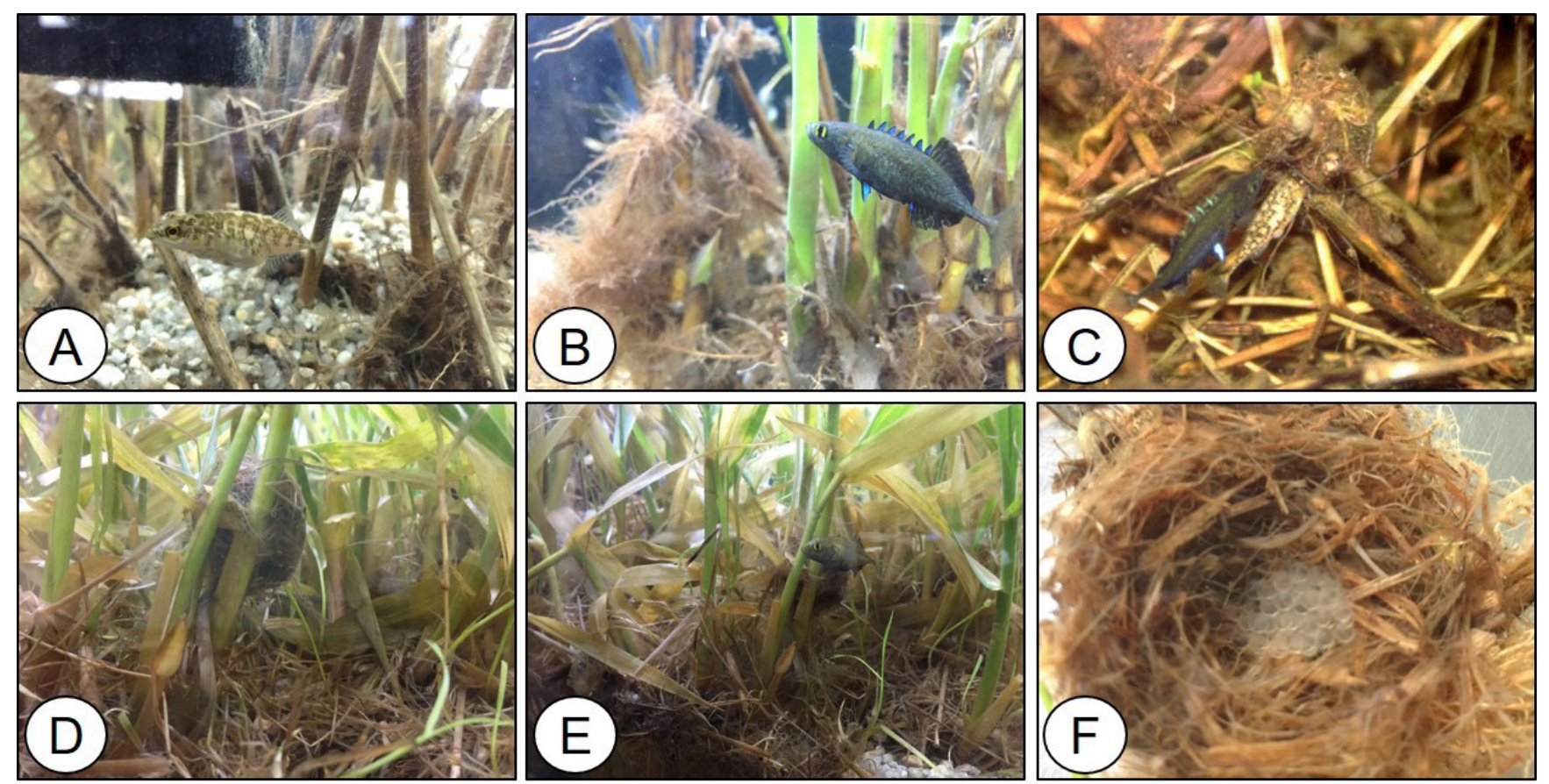

Fig. 1. Reproductive characteristics and spawning behavior of Pungitius kaibarae. (A) A mature female, (B) a mature male with nuptial coloration (whole black body with blue dorsal spines and yellow eyes), (C) spawning and fertilization in the nest, (D) nest with fertilized eggs, (E) a male guarding nest, (F) observation of fertilized eggs.

blastomere became smaller (Fig. 2F). The morula cells continued to reduce in size and appeared as a cell mass. At 9 HPF, eggs reached the blastula stage, continuous cell division took place, and there was an increase in the number of blastomere cells (Fig. $2 \mathrm{G})$.

At $16 \mathrm{HPF}$, eggs reached the gastrula stage (Fig. 2H). At this stage, epiboly and blastoderm were expanded over the yolk surface, covering $<25 \%$ and $<50 \%$ of the surface (Fig. 2I) at 16 and 18.5 HPF, respectively. At 21.5 HPF, embryo formation and elongation were observed (Fig. 2J). At 24.5 HPF, paired optic lobes were formed at the posterior head (Fig. 2K). At 28 HPF, 6-8 somites appeared in the body, and optic lobes were differentiated as optic vesicles (Fig. 2L). At $42.5 \mathrm{HPF}$, the optic vesicles were further differentiated as optic cups, and accumulation of pigment was observed in the dorsal part of the body and near the yolk sac (Fig. 2M). During this period, the heartbeat was found to be $70-80$ movements per min. At $75.5 \mathrm{HPF}$, the pigment accumulated in most areas of the eyecups and appeared not only in the dorsal part of the body but also in the mid-brain (Fig. 2N). In addition, the mouth and tail were formed at this stage. At 96 HPF, the embryo hatched (Fig. 2O). Newly hatched larvae had visible pairs of the pectoral fin and measured $5.67 \pm$
$0.50 \mathrm{~mm}$ in TL. The hindguts and anuses were formed, and a rudimentary small fin was observed between the yolk and anus.

At $1 \mathrm{~d}$ posthatching (DPH), the TL of the larvae was $6.01 \pm$ $0.11 \mathrm{~mm}$ and approximately $50 \%$ of the yolk was absorbed (Fig. $3 \mathrm{~A})$. At $5 \mathrm{DPH}(\mathrm{TL}=7.93 \pm 0.95 \mathrm{~mm})$, the yolk was completely absorbed. At this stage, the swim bladder was observed, and larvae began to feed voraciously on Artemia with developing jaws. In the ventral part of the head, gill filaments were observed. The membranous fin was folded. The terminal part of the notochord grew upward, and rudimentary caudal fin rays ( $\mathrm{n}=10-12)$ had developed, forming a heterocercal tail (Fig. 3B). At $10 \mathrm{DPH}$ (TL $=9.65 \pm 0.41 \mathrm{~mm}$ ), the area of the digestive tract increased in the abdominal cavity. Dorsal, anal, and caudal fins were separated by folding of the membranous fin, and fin rays were formed. The ventral lobe in the caudal fin grew and increased in number ( $\mathrm{n}=16-18$ ), forming a homocercal tail (Fig. 3C). At $15 \mathrm{DPH}$ $(\mathrm{TL}=10.40 \pm 1.05 \mathrm{~mm}$ ), the dorsal spines began to appear and the caudal fin was completely formed (Fig. 3D). At $20 \mathrm{DPH}$ (TL $=10.61 \pm 0.63 \mathrm{~mm}$ ), dorsal spines were developing, but gill filaments were not observed owing to formation of the operculum. The snout had become elongated (Fig. 3E). At $25 \mathrm{DPH}$ (TL = $18.54 \pm 1.20 \mathrm{~mm}$ ), the dorsal spines were formed completely, 

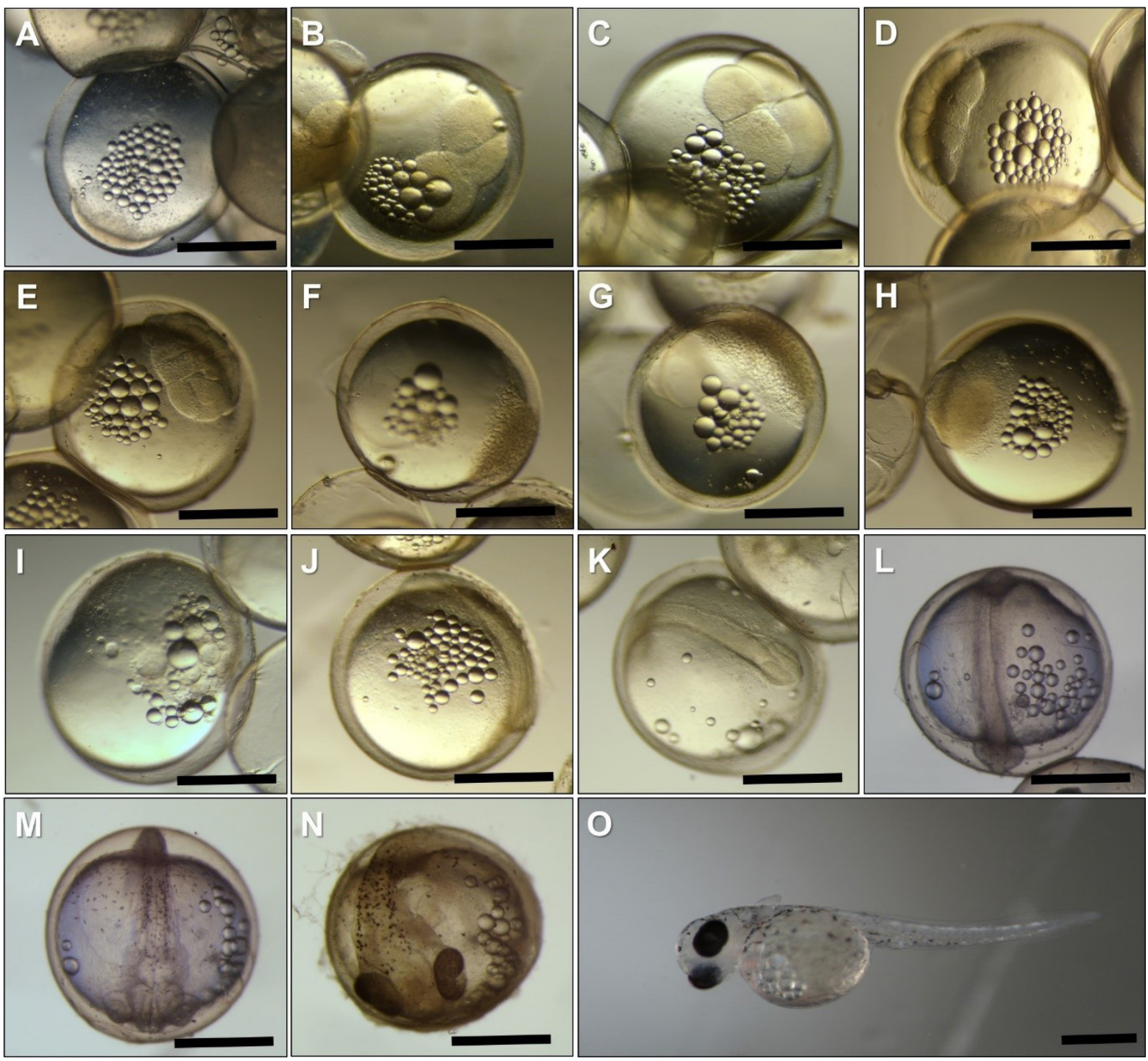

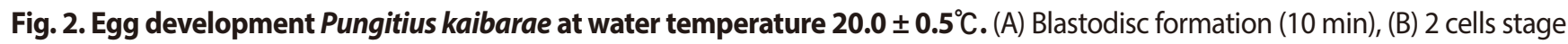
(30 min), (C) 4 cells stage (1 h), (D) 8 cells stage ( 1 h $30 \mathrm{~min}),(E) 16$ cells stage $(2 \mathrm{~h}),(\mathrm{F})$ morula stage $(4 \mathrm{~h}),(\mathrm{G})$ blastula stage $(5 \mathrm{~h}),(\mathrm{H})$ early gastrula stage $(16 \mathrm{~h})$; (I) mid gastrula stage $(18 \mathrm{~h} 30 \mathrm{~min})$, (J) late gastrula stage $(21 \mathrm{~h} 30 \mathrm{~min})$, (K) formation of embryo $(24 \mathrm{~h} 30$ $\mathrm{min})$, (L) formation of somite ( $28 \mathrm{~h}$ ), (M) blood circulation and pigment on body (42 $\mathrm{h} 30 \mathrm{~min}),(\mathrm{N})$ formation of mouth and tail $(75 \mathrm{~h}$ $30 \mathrm{~min}$ ), (0) hatching (96 h). Scale bar indicates $500 \mu \mathrm{m}$ (1 $\mathrm{mm}$ in hatched larva).

the snout was more elongated, and the lower jaw was longer than the upper jaw. At this stage, it showed typical morphological characteristics of an adult fish (Fig. 3F).

\section{Measurement of nest area and number of eggs}

During the spawning trial in the indoor tank, 55 nests were built from $21^{\text {st }}$ April to $30^{\text {th }}$ June (Fig. 4). The average area of the nest and number of eggs were $259.56 \pm 101.39 \mathrm{~mm}^{2}(75.18-$ $506.04)$ and $155.33 \pm 114.12(0-437)$, respectively. There were 8 nests without eggs.

\section{Discussion}

The spawning period of $P$. kaibarae has been reported to be between February and June, and the peak period is from early March to late April (Chae \& Yang, 1993). Our results indicated that reproductive performance continued until late June. This prolonged spawning could be due to our study being conducted 

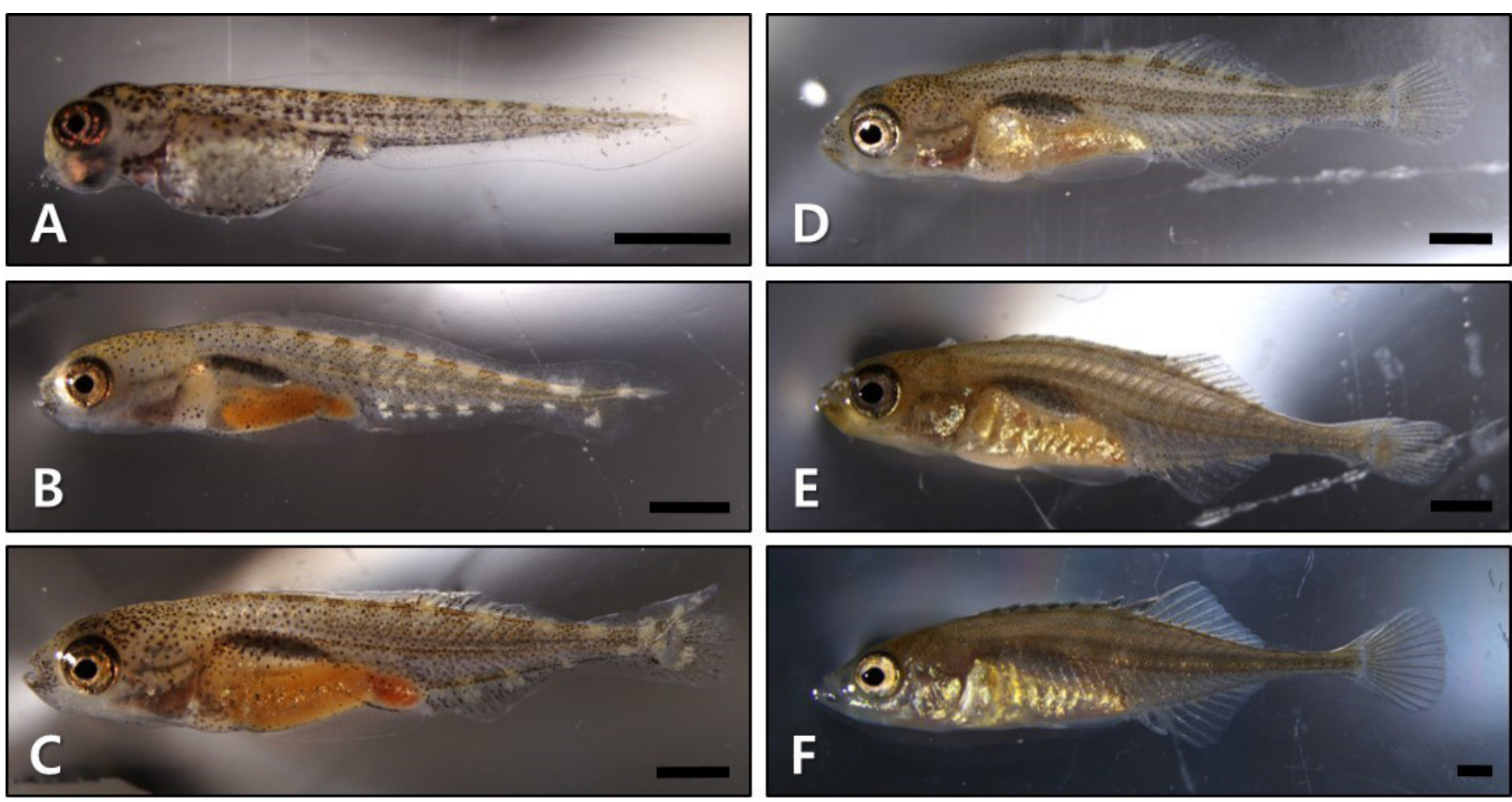

Fig. 3. The larvae and juvenile development of Pungitius kaibarae. (A) 1 day post hatching (DPH) with $6.01 \pm 0.11 \mathrm{~mm}$ of total length (TL), (B) $5 \mathrm{DPH}$ with $7.93 \pm 0.95 \mathrm{~mm}$ of TL, (C) $10 \mathrm{DPH}$ with $9.65 \pm 0.41 \mathrm{~mm}$ of TL, (D) $15 \mathrm{DPH}$ with $10.40 \pm 1.05 \mathrm{~mm}$ of TL, (E) 20 DPH with $10.61 \pm 0.63 \mathrm{~mm}$ of TL, (F) $25 \mathrm{DPH}$ with $18.54 \pm 1.20 \mathrm{~mm}$ of TL. Scale bars indicate $1 \mathrm{~mm}$.


Fig. 4. Area and number of eggs from a nest of Pungitius kaibarae observed in the indoor tank. The area $\left(\mathrm{mm}^{2}\right)$ of 55 nests was calculated by measurement of each width $(\mathrm{mm})$ and height $(\mathrm{mm})$.

in the indoor tank rather than in the wild environment, as in the previous study. Moreover, the different latitudes of their habitats or different populations may also be a factor for prolonged spawning of the fish. The diversity in spawning period among different populations of the threespine stickleback Gasterosteus aculeatus (G. aculeatus) and the ninespine stickleback Pungitius pungitius (P. pungitius) has been previously reported (Heins et al., 2003; Ishikawa \& Kitano, 2020). In this regard, future studies on the reproductive cycle of $P$. kaibarae in various habitats could provide more detailed information. 
We aimed to illustrate the spawning behavior and describe the embryonic and larval development of $P$. kaibarae reared in indoor tanks. Coste (1848) first reported the nest building of stickleback fish with $G$. pungitius. Since then, several studies have reported the nest building of various other stickleback species (Cunningham, 1887; FitzGerald, 1993; Hancock, 1852; McKenzie \& Keenleyside, 1970; Morris, 1958). Park \& Lee (1999) reported that $P$. kaibarae with a longer TL could occupy territories more easily than smaller ones. In G. aculeatus, similar results have been reported: fish that are larger, older, and have a brighter nuptial color are dominant in reproductive behavior and occupying their territories (Fraipont et al., 1993; FitzGerald, 1993). Moreover, P. kaibarae show a hetero-sexual territorial system; both males and females build nests in their territories during the reproductive period (Morris, 1958; Park \& Lee, 1999). However, the female's territory is lost by the male's aggressive expelling behavior just after spawning and fertilization; the aggressive behavior of males could be due to their strong parental care. Interestingly, Chae \& Yang (1993) reported that males built two nests in an indoor tank. We suspect that the male built two nests because of territorial competition among males within a cramped tank. In the present study, we did not observe two nests built by a male.

We observed two batches of fertilized eggs with different developmental stages in a few nests. Pianka (1983) suggested two types of sexual selection. One is intrasexual selection, which represents competition for the best combination among members of the same gender, and the other is epigamic or intersexual selection, which is operated by the preference between different genders. In this regard, epigamic or intersexual selection may have occurred in P. kaibarae, as the nest-guarding males could mate with other females.
The fertilized eggs of $P$. kaibarae were spherical, demersal, adhesive, and transparent. The average diameter of each fertilized egg was $1.43 \pm 0.07 \mathrm{~mm}$, which was similar to that of $G$. aculeatus and P. pungitius eggs (Table 1). Most of the characteristics of egg and larval development were in accordance with the general view by Swarup (1958) on the study of G. aculeatus, the representative species of the family Gasterosteidae. However, there were differences in hatching time and the number of oil droplets.

In G. aculeatus, the elapsed time for hatching was $192 \mathrm{~h}$ at $18^{\circ} \mathrm{C}-19^{\circ} \mathrm{C}$. However, the elapsed time for hatching in $P . k a i-$ barae was $96 \mathrm{~h}$ in $20.0 \pm 0.5^{\circ} \mathrm{C}$ water temperature. Although the water temperature in the present study was higher than that in the previous study with G. aculeatus, the elapsed time for hatching of $P$. kaibarae was approximately half that of G. aculeatus. The reason for this difference is not yet known. In addition, the TL of newly hatched P. kaibarae was more than that of G. aculeatus, although adult $G$. aculeatus was larger than P. kaibarae. The elapsed time for hatching in fish is associated with survival rate in the early developmental stage; fast hatching reduces predation during the most vulnerable period (Kim \& Zhang, 1994). A comparison of elapsed time for hatching and survival rate among stickleback species will be conducted in a future study. In P. kaibarae, approximately 20-30 oil droplets were observed during embryonic development, and newly hatched larvae had less than ten oil droplets in their yolk. However, in G. aculeatus, the number of oil droplets was less than 20 during embryonic development, and newly hatched larvae had single oil droplets in their yolk (Swarup, 1958). This is a useful characteristic for the identification of species belonging to Gasterosteidae.

We measured the nest area of $P$. kaibarae from an indoor tank, and the average nest area was found to be $259.56 \pm 101.39$

Table 1. Comparison of fertilized egg diameter, place of nest and its area among three stickleback species

\begin{tabular}{|c|c|c|c|c|c|c|}
\hline Species & $\begin{array}{l}\text { Diameter of fertilized } \\
\text { egg }(\mathrm{mm})\end{array}$ & $\begin{array}{l}\text { Elapsed time for hatching } \\
\text { (water temperature) }\end{array}$ & $\begin{array}{l}\text { Total length of hatched } \\
\text { larvae }(\mathrm{mm})\end{array}$ & Place of nest & Nest area $\left(\mathrm{mm}^{2}\right)$ & References \\
\hline Gasterosteus aculeatus & $1.2-1.7$ & $\begin{array}{l}192 \mathrm{~h} \\
\left(18^{\circ} \mathrm{C}-19^{\circ} \mathrm{C}\right)\end{array}$ & 4.71 & Bottom & $1,901 \pm 842$ & $\begin{array}{l}\text { Barber et al. (2001) } \\
\text { Swarup (1958) }\end{array}$ \\
\hline Pungitius pungitius & 1.42 & Not measured & Not measured & $\begin{array}{l}\text { Stems/branches of } \\
\text { waterweed off } \\
\text { bottom }\end{array}$ & Not measured & Heins et al. (2003) \\
\hline \multirow[t]{2}{*}{ Pungitius kaibarae } & $1.43 \pm 0.07$ & $\begin{array}{l}96 \mathrm{~h} \\
\left(20.0 \pm 0.5^{\circ} \mathrm{C}\right)\end{array}$ & $5.67 \pm 0.50$ & \multirow{2}{*}{$\begin{array}{l}\text { Stems/branches of } \\
\text { waterweed off } \\
\text { bottom }\end{array}$} & $259.56 \pm 101.39$ & Present study \\
\hline & $1.6 \pm 0.1^{1)}$ & Not measured & Not measured & & $866.30 \pm 129.51^{2)}$ & Chae \& Yang (1993) \\
\hline
\end{tabular}

\footnotetext{
${ }^{1)}$ The value was measured from deposited eggs in the nest.

${ }^{2)}$ The value was total area, the area covered by minimum area polygon enclosing all visible nest material.
} 
$\mathrm{mm}^{2}$. In a previous study on G. aculeatus, the average nest area was larger than that of P. kaibarae. However, Chae \& Yang (1993) reported that the nest area of $P$. kaibarae was $866.30 \pm 129.51$ $\mathrm{mm}^{2}$, which was larger than that in the present study (Table 1). The reason for this difference could be the calculation of nest area; the bulk area was calculated in the present study, whereas the total area was calculated in the previous study. Through the trial in the indoor tank, spawning was observed until late June; observations suggested that the reproductive period in captivity could be longer than that in the wild environment. Moreover, this prolonged spawning could be used as a technology for improving artificial seed production.

Reproductive and early development characteristics are used as fundamental data for the classification and conservation of certain fish species (Seo et al., 2006). This study is the first illustration of the spawning behavior and egg and larval development of $P$. kaibarae using photographs. The study findings would be useful as preliminary data for future studies on the reproductive biology of $P$. kaibarae.

\section{Competing interests}

No potential conflict of interest relevant to this article was reported.

\section{Funding sources}

This study was supported by a grant from National Institute of Fisheries Science, Korea (R2021040).

\section{Acknowledgements}

Not applicable.

\section{Availability of data and materials}

Upon reasonable request, the datasets of this study can be available from the corresponding author.

\section{Ethics approval and consent to participate}

All experiments were approved by the IACUC of National Institute of Fisheries Science, Korea (2019-NIFS-IACUC-23).

\section{ORCID}

In Joon Hwang

Si Woo Lee

Young Sim Han

Kyeong Hwan Kim https://orcid.org/0000-0001-5740-3925 https://orcid.org/0000-0003-0933-347X https://orcid.org/0000-0002-2782-9682 https://orcid.org/0000-0002-1332-7294

\section{References}

Bae HG, Suk HY. Population genetic structure and colonization history of short ninespine sticklebacks (Pungitius kaibarae). Ecol Evol. 2015;5:3075-89.

Bae HG, Lee YJ, Jeon HB, Kim DY, Won H, Park S, et al. The complete mitochondrial genomes of three geographical lineages in short ninespine stickleback (Pungitius kaibarae) complex and their phylogenetic implication. Mitochondrial DNA B Resour. 2017;2:500-1.

Barber I, Nairn D, Huntingford FA. Nests as ornaments: revealing construction by male sticklebacks. Behav Ecol. 2001;12:390-6.

Blaxter JHS. The early life history of fish. Berlin: Springer Verlag; 1974.

Chae BS, Yang HJ. Spawning and growth of eightspine stickleback, Pungitius sinensis kaibarae (Tanaka) (Gasterosteidae, Pisces), in the Chayang stream, a tributary of Kumho river, Korea. Korean J Zool. 1993;36:181-92.

Coste P. Nidification des épinoches et des épinochettes. Mem Pres Div Savants Acad Sci Inst Natl Fr. 1848;10:574-88.

Cunningham JT. IV.-The eggs and larvae of teleosteans. Earth Environ Sci Trans R Soc Edinb. 1887;33:97-136.

FitzGerald GJ. The reproductive behavior of the stickleback. Sci Am. 1993;268:80-5.

Fraipont M, FitzGerald GJ, Guderley H. Age-related differences in reproductive tactics in the three-spined stickleback, Gasterosteus aculeatus. Anim Behav. 1993;46:961-8.

Hahlbeck E, Katsiadaki I, Mayer I, Adolfsson-Erici M, James J, Bengtsson BE. The juvenile three-spined stickleback (Gasterosteus aculeatus L.) as a model organism for endocrine disruption II-kidney hypertrophy, vitellogenin and spiggin induction. Aquat Toxicol. 2004;70:311-26.

Hancock A. Observations on the nidification of Gasterosteus aculeatus and Gasterosteus spinachia. Ann Mag Nat Hist 1852;10:241-8.

Heins DC, Johnson JM, Baker JA. Rerpdoductive ecology of the nine-spined stickleback from south-central Alaska. J Fish Biol. 2003;63:1131-43.

Hwang DS, Song HB, Lee JS. Complete mitochondrial genome of the Amur stickleback Pungitius kaibarae (Gasterosteiformes, Gasterosteidae). Mitochondrial DNA. 2012;23:313-4.

Ishikawa A, Kitano J. Diversity in reproductive seasonality in the three-spined stickleback, Gasterosteus aculeatus. J Exp Biol. 2020;223:jeb208975. 
Jang MH, Yoon JD, Chae BS, Joo GJ. Molecular phylogeny of Pungitius kaibarae from mitochondrial DNA sequences in selected streams flowing into the East Sea. Korean J Ecol Environ. 2006;39:265-70.

Kim IS. Illustrated encyclopedia of fauna and flora of Korea. Vol. 37. Freshwater fishes. Yeongi: Ministry of Education of Korea; 1997.

Kim IS, Yoon CH, Lee JH. Morphological variation and karyotype of the Korean species of sticklebacks, (Pisces, Gasterosteidae) in Korea. Korean J Syst Zool. 1989;5:107-19.

Kim S, Zhang CI. Fish ecology. Seoul: Seoul Press; 1994.

McKenzie JA, Keenleyside MHA. Reproductive behavior of ninespine sticklebacks (Pungitius pungitius (L.)) in South Bay, Manitoulin Island, Ontario. J Fish Res Board Can. 1970;48:55-61.

Ministry of Environment of Korea. Conservation and management laws of wildlife. Law No. 10977 (2016).

Morris D. The reproductive behaviour of the ten-spined stickleback (Pygosteus pungiyius L.). Behav Suppl. 1958;6:1-154.

Park SR, Lee JH. Territorial behavior of eightspine stickleback, Pungitius sinensis kaibarae in Korea. Korean J Ecol. 1999;22:163-7.

Park SR, Lee JH, Cheong S. Comparison of reproductive behaviors between two species of Eghtspine sticlebacks (genus: Pungitius). Korean J Biol Sci. 2001;5:127-32.

Pianka ER. Evolutionary ecology. 3rd ed. New York: Harper \& Row; 1983.

Seo WI, Han KH, Yoon SM, Kim CC, Hwang SY, Lee SH, et al. Early life history of the Liobagrus obesus (Pisces, Amblycipitidae). Dev Reprod. 2006;10:41-5.

Sokołowska E, Kulczykowska E. Annual reproductive cycle in two free living populations of three-spined stickleback (Gasterosteus aculeatus L.): patterns of ovarian and testicular development. Oceanologia. 2006;48:103-24.

Swarup H. Stages in the development of the stickleback Gasterosteus aculeatus (L.). J Embryol Exp Morphol. 1958;6:373-83. 